\title{
Laboratory testing of a long expansion rock bolt support for energy-absorbing applications
}

\author{
Krzysztof Skrzypkowski ${ }^{1, *}$ \\ ${ }^{1}$ AGH University of Science and Technology, Faculty of Mining and Geoengineering, 30 A. \\ Mickiewicz Av., 30-059 Kraków, Poland
}

\begin{abstract}
The main purpose of rock support and reinforcement in underground mining is to maintain excavations safe and open for their intended lifespan. The basic type of rock mass reinforcement method both in ore and hard coal mining is rock bolt support. Very often, existing bolt support systems are not always capable of providing a reliable controlled performance. Therefore, in recent years energy-absorbing bolts which are exposed to dynamic loading, for example from rock burst caused by high rock stresses, earthquakes, or blasting have appeared. In this article particular attention was paid to short and long expansion bolts. Quasi-static tests of expansion bolts were carried out at the laboratory test facility in simulated mining conditions, especially for the KGHM Polska Miedź S.A. mines. In the underground mines of the Legnica-Głogów Copper District (LGOM) the main way to protect the room excavation is rock bolt support with a length from $1.2 \mathrm{~m}$ to $2.6 \mathrm{~m}$. Rock bolt support longer than $2.6 \mathrm{~m}$ is considered as additional support of excavations and is increasingly being used to reinforce the roofs. The comparisons of energy-absorbing short and long expansion bolts with a length of $1.8 \mathrm{~m}, 3.6 \mathrm{~m}$ and $5.2 \mathrm{~m}$ were presented. In addition, for elastic and plastic range of each bolts were determined.
\end{abstract}

\section{Introduction}

Many mines around the word, for example those in Poland, Chile, Canada, Australia and South Africa, are currently being operated at depths greater than $1000 \mathrm{~m}$. At such levels, the rock mass can be highly stressed causing an increase in the severity and frequency of rock bursts. The rejected rock mass can reach velocities between 3 and $10 \mathrm{~m} / \mathrm{s}$ with corresponding energy levels varying from 10 to $50 \mathrm{~kJ} / \mathrm{m}^{2}$ [1]. Mining supports must be adapted to the natural hazards, especially rock bursts, whose intensification will be increasing with the increase in depth of exploitation [2, 3]. The consequence of the execution of any underground excavation is the formation of a new equilibrium state defined by the difference between the original state of stress and displacement. This is accompanied by specific geotechnical processes, their type and intensity being a function of the stress state and geomechanical properties of the rocks surrounding the excavated area. In general, the magnitude of the so-called rock mass pressure is determined by the energy

Corresponding author: skrzypko@agh.edu.pl 
changes that characterize the energy balance equation for any point in the rock medium by the following formula:

$$
A_{g}+A_{t}+A_{e}+A_{d}=A_{o s}+A_{o r}+L_{z}+A_{k}+A_{r}
$$

where:

$\mathrm{A}_{\mathrm{g}}$ - density of energy caused by gravitational stresses,

$A_{t}-$ density of energy caused by tectonic stresses,

$A_{e}$ - density of energy caused by the effects of stresses from the past influences of exploitation,

$A_{d}$ - density of kinetic energy resulting from the impact of a possible bumps,

$A_{o s}$ - density of energy of elastic deformation,

$\mathrm{A}_{\text {or }}$ - density of energy used for rheological deformation,

$\mathrm{L}_{\mathrm{z}}$ - work worn for destruction - fracturing (for formation a new surfaces),

$A_{k}$ - density of kinetic energy used for the possible movement of the fractured rock area,

$\mathrm{A}_{\mathrm{r}}$ - density of dissipated energy used for thermal, friction, acoustic, seismic effects.

Based on the above energy balance, can be made the following classification [4].

Table 1. Classification of energy balance.

\begin{tabular}{|c|c|c|c|}
\hline No & Energy balance & & Support of the excavation \\
\hline 1. & $\begin{array}{c}\mathrm{A}_{\mathrm{os}}>0 \\
\mathrm{~A}_{\mathrm{or}}=\mathrm{L}_{\mathrm{z}}=\mathrm{A}_{\mathrm{k}}=\mathrm{A}_{\mathrm{r}}=0 \\
\mathrm{~A}_{\mathrm{g}}+\mathrm{A}_{\mathrm{t}}+\mathrm{A}_{\mathrm{e}}+\mathrm{A}_{\mathrm{d}}=\mathrm{A}_{\mathrm{os}}\end{array}$ & $\begin{array}{l}(2) \\
(3) \\
(4)\end{array}$ & $\begin{array}{l}\text { The excavation can be carried out without a } \\
\text { support and will retain the required stability } \\
\text { and functionality throughout its life, as no } \\
\text { fractures are formed. }\end{array}$ \\
\hline 2. & $\begin{array}{c}\mathrm{A}_{\mathrm{os}}>0 \\
\mathrm{~L}_{\mathrm{z}}>0 \\
\mathrm{~A}_{\mathrm{or}}=\mathrm{A}_{\mathrm{k}}=\mathrm{A}_{\mathrm{r}}=0 \\
\mathrm{~A}_{\mathrm{g}}+\mathrm{A}_{\mathrm{t}}+\mathrm{A}_{\mathrm{e}}+\mathrm{A}_{\mathrm{d}}=\mathrm{A}_{\mathrm{os}}+\mathrm{L}_{\mathrm{z}}\end{array}$ & $\begin{array}{l}(5) \\
(6) \\
(7) \\
(8)\end{array}$ & $\begin{array}{l}\text { Around the excavation a fracture zone is } \\
\text { formed. The excavation must be supported } \\
\text { because will be exposed to static loads. }\end{array}$ \\
\hline 3. & $\begin{array}{c}\mathrm{A}_{\mathrm{os}}>0 \\
\mathrm{~A}_{\mathrm{or}}>0 \\
\mathrm{~A}_{\mathrm{or}}=\mathrm{A}_{\mathrm{k}}=\mathrm{A}_{\mathrm{r}}=0 \\
\mathrm{~A}_{\mathrm{g}}+\mathrm{A}_{\mathrm{t}}+\mathrm{A}_{\mathrm{e}}+\mathrm{A}_{\mathrm{d}}=\mathrm{A}_{\mathrm{os}}+\mathrm{L}_{\mathrm{z}}\end{array}$ & $\begin{array}{l}(9) \\
(10) \\
(11) \\
(12)\end{array}$ & $\begin{array}{l}\text { The excavation must be supported, but due to } \\
\text { the lack of fractures, the support will be } \\
\text { exposed to deformation loads and the } \\
\text { excavation itself will be under convergence } \\
\text { successively, although no stress changes in } \\
\text { its vicinity will occur. The intensity of } \\
\text { convergence will depend on the rheological } \\
\text { properties of the rock medium and the } \\
\text { stresses in the rock mass. }\end{array}$ \\
\hline 4. & $\begin{aligned} & \mathrm{A}_{\mathrm{os}}>0 \\
& \mathrm{~A}_{\mathrm{or}}>0 \\
& \mathrm{~L}_{\mathrm{z}}>0 \\
& \mathrm{~A}_{\mathrm{or}}=\mathrm{A}_{\mathrm{r}}=0 \\
& \mathrm{~A}_{\mathrm{g}}+\mathrm{A}_{\mathrm{t}}+\mathrm{A}_{\mathrm{e}}+\mathrm{A}_{\mathrm{d}}= \\
&=\mathrm{A}_{\mathrm{os}}+\mathrm{A}_{\mathrm{or}}+\mathrm{L}_{\mathrm{z}}\end{aligned}$ & $\begin{array}{l}(13) \\
(14) \\
(15) \\
(16) \\
(17)\end{array}$ & $\begin{array}{l}\text { The excavation must be supported and the } \\
\text { support will be subjected to both static and } \\
\text { deformation loads, while the excavation itself } \\
\text { will be successively under convergence even } \\
\text { though there will be changes in the stress } \\
\text { state in its vicinity. }\end{array}$ \\
\hline 5. & $\begin{array}{r}\mathrm{A}_{\mathrm{os}} \approx 0 \\
\mathrm{~A}_{\mathrm{or}} \approx 0 \\
\mathrm{~L}_{\mathrm{z}}>0 \\
\mathrm{~A}_{\mathrm{k}}>0 \\
\mathrm{~A}_{\mathrm{r}} \approx 0 \\
\mathrm{~A}_{\mathrm{g}}+\mathrm{A}_{\mathrm{t}}+\mathrm{A}_{\mathrm{e}}+\mathrm{A}_{\mathrm{d}}=\mathrm{L}_{\mathrm{z}}+\mathrm{A}_{\mathrm{k}}\end{array}$ & $\begin{array}{l}(18) \\
(19) \\
(20) \\
(21) \\
(22) \\
(23)\end{array}$ & $\begin{array}{l}\text { In view of the existence of a fractures zone } \\
\text { and excess energy in the system around the } \\
\text { excavation (the latter converts into kinetic } \\
\text { energy, specifically the energy of the } \\
\text { fractured rock elements within the fractures } \\
\text { zone. We will deal with the phenomenon of } \\
\text { rock burst. }\end{array}$ \\
\hline
\end{tabular}

Unfortunately, despite the great simplicity of the presented balance, the creation of dynamic assessments characterizing the possibility of occurrence of certain phenomena is, unfortunately, much more complicated, since the complexity of the rock formation, 
expressed in its form: discontinuity, heterogeneity, anisotropy or nonlinearity, is further enhanced by the spatial structure of the excavations. Faithful description of phenomena occurring in a rock mass outcrop are prone to failure.

The efficiency of the rock bolting is determined by two groups of factors:

a)geotechnical conditions understood as the effect of stress interactions and geotechnical properties of rocks,

b)technical and organizational factors, which are expressed primarily in the quality of workmanship and in the current control of the support.

In view of such conditions, it will be apparent that the rock bolting is one of many types of support and only in certain situations its use is justified.

Rock bolt support fulfills three functions as:

a)reinforce the rock mass to strengthen it and to control bulking,

b)retain broken rock to prevent fractured block failure and unraveling,

c)hold fractured blocks and securely tie back the retaining elements to stable ground.

The mechanics of rock support is very complex, and no models exist that can fully explain the interaction of various support components in a rock support systems $[5,6]$.

\section{Energy-absorbing bolts}

Rock bolt support is used in underground mining primarily in ore mining, although increasingly this method of rock reinforcement can also be found in hard coal mines. In mining practice there are different construction solutions of bolts co-operating in different systems with rock mass formations and other types of supports.

The variety of conditions in which the rock bolt support is used makes it suitable for securing the roof and the excavation work as a stand alone or reinforcing rock bolt support. It also serves to suspend various items of mining equipment. Rock bolt can be divided into five categories $[7,8]$ :

Table 2. Division of rock bolt support.

\begin{tabular}{|c|l|l|l|}
\hline Criterion & \multicolumn{3}{|c|}{ Type of rock bolts } \\
\hline Type of material & $\begin{array}{l}\text { Steel - in the form of } \\
\text { rods, pipes, sheets, } \\
\text { strings and cables }\end{array}$ & Wooden rods & $\begin{array}{l}\text { Composite materials } \\
\text { in the form of rods, } \\
\text { pipes and strings }\end{array}$ \\
\hline Mechanism of action & $\begin{array}{l}\text { Grouted - mounted in } \\
\text { the rock mass by } \\
\text { means of various types } \\
\text { of cement binders or } \\
\text { resin cartridges }\end{array}$ & $\begin{array}{l}\text { Mechanical - mounted } \\
\text { in the rock mass by } \\
\text { means of shell head } \\
\text { spread out inside a a } \\
\text { borehole }\end{array}$ & $\begin{array}{l}\text { Friction - acting on } \\
\text { the principle of } \\
\text { friction occurring } \\
\text { between bolt and } \\
\text { borehole }\end{array}$ \\
\hline Method of mounting & $\begin{array}{l}\text { Continuous - the bolt } \\
\text { is fixed in the hole } \\
\text { along its entire length } \\
\text { by applying adhesive } \\
\text { resin catridges or a } \\
\text { suitable cement binder } \\
\text { and on the friction } \\
\text { principle. }\end{array}$ & $\begin{array}{l}\text { Point - this type is } \\
\text { characteristic for } \\
\text { wedge, jaw or short } \\
\text { encapsulated bolts, it } \\
\text { allows the bolt be pre- } \\
\text { tensioning }\end{array}$ & \\
\hline Length & $\begin{array}{l}\text { Short - up to 2.7 m in } \\
\text { (in hard coal and ore }\end{array}$ & $\begin{array}{l}\text { Long - up to 12 m (in } \\
\text { hard coal mining in }\end{array}$ & \\
\hline
\end{tabular}




\begin{tabular}{|l|l|l|l|}
\hline & mining in Poland) & $\begin{array}{l}\text { Poland) and up to 7m } \\
\text { in copper ore mining } \\
\text { in Poland }\end{array}$ & \\
\hline Taking over a load & $\begin{array}{l}\text { Rigid - with } \\
\text { satisfactory strength, } \\
\text { breaking in when } \\
\text { taking over the load } \\
\text { near the limit of } \\
\text { strength of bolt rod, } \\
\text { with relatively small } \\
\text { deformation capacity }\end{array}$ & $\begin{array}{l}\text { Yelding - capable of } \\
\text { deformation, significant } \\
\text { relatively low carrying }\end{array}$ & $\begin{array}{l}\text { Energy-absorbing of } \\
\text { canamic load } \\
\text { characterized by high } \\
\text { load carrying capacity } \\
\text { and the ability to carry } \\
\text { relatively high } \\
\text { displacement and } \\
\text { deformation }\end{array}$ \\
\hline
\end{tabular}

A modern, efficient rock bolt support provided for dynamic loading conditions must be made of a material of higher tensile strength and at the same time maintain the required load carrying capacity at its axial displacement. In different scientific centers in the world, in mines and other companies, bolt support is constructed with different stress-strain characteristics and dynamic load parameters. A rock bolt capable of absorbing kinetic energy from loads must be able to yield with the ground movements and also deform plastically over large distance, at high displacement rates [9]. Energy-absorbing bolts are used as part of rock support systems in underground mines that are exposed to detonating explosives and rock burst. In addition, most importantly a special bolt construction are characterized by their high load capacity and also their large deformation capacity. The energy-absorbing bolts have been studied almost 30 years the world. The first concept of such a bolt, the so-called ,cone bolt" was proposed in South Africa in the early 1990s [10]. The ,cone bolt" was modified later for resin grout in Canada [1]. Another bolts which have variable geometry along entire length are: „Durabar” [11], „D” 5], „CTw” [12]. „NMX” [13]. There are also bolts that have an additional absorbing element added from the roof side of the excavation, e.g. „Deformable component" [14] or on the bottom of the borehole, e.g. „Dynatork” [15], „Yiel-Lok” [16] or inside the borehole (the so-called absorber), e.g. „Roofex” [17], „Garford” [18], „He” [19], „DAP” [20]. A few of those bolts schematics which are available so far are briefly presented on the Fig. 1. The capacity of rock bolt reaches over $300 \mathrm{kN}$, while the value of the absorbed energy reaches $6,6 \cdot 10^{4} \mathrm{~J}$. The authors of the research study report the values of acceptable displacements up to $0.6 \mathrm{~m}$. The disclosed displacements are the result of deformation of the bolt material in the elastic and plastic range as well as the properties of the bonding materials used (cement, resin) and the specific construction and applied mechanisms, the so-called energy-absorbers. It should be emphasized here that too high limits of strain or elongation of the bolt from the borehole, even with the high bolting capacity itself, can cause premature loss of stability of the excavation, for example due to exceeding the limit value of deflection in the bolted roof. This part of the problem should always be considered when designing a rock bolt support intended for use in conditions of dynamic loads of rock mass. 
a)

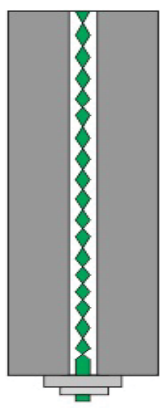

b)

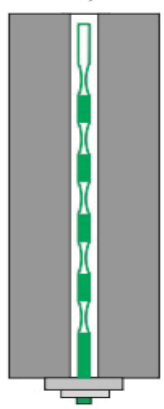

c)

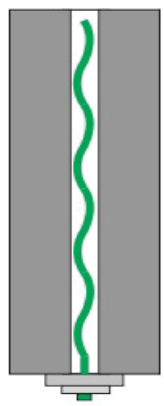

d)

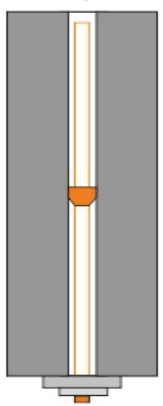

e)

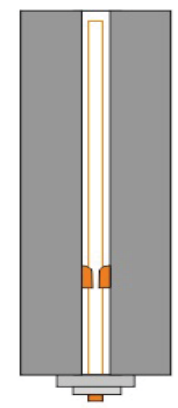

f)

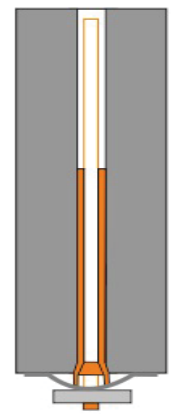

k)
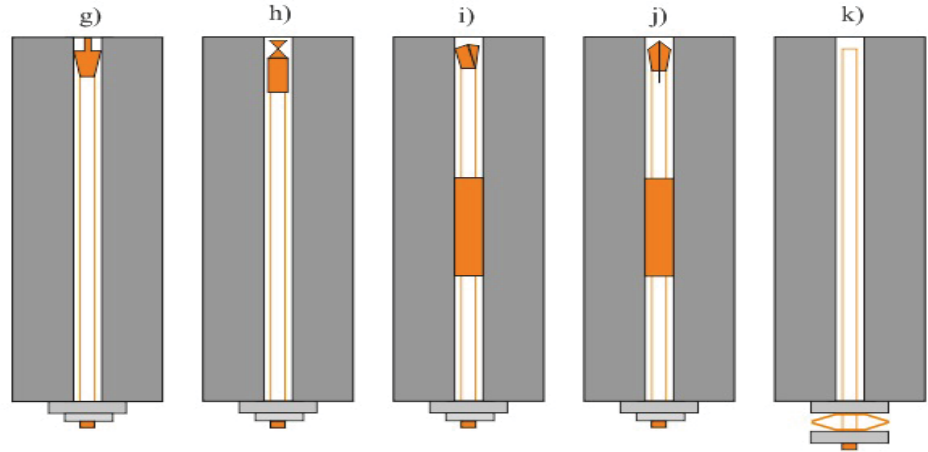

Fig. 1. Simplified mechanisms for absorbing of energy by rock bolts; a) "CTw", b) "D", c) Durabar", d) "Roofex", e) "Garford", f) "He", g) "Modified Cone bolt", h) "Dynatork" i) "DAP”, j) "NMX", k) "Deformable component".

\section{Laboratory test facility}

Quasi-static tests of expansion rock bolts were carried out at the laboratory test facility in simulated mining conditions, in particular for the KGHM Polska Miedź S.A. mine. Studies were carried out using a consistent methodology. In the quasi-static load mode, the rock bolts were stretched and broken by the use of maximum force in the shortest possible time (approximately $4 \mathrm{~s}$ ) resulting from the power of the pump. Displacement and force sensors were connected to a QuantumX MX840 universal measuring amplifier via 15-pin plugs. During the process of rock bolt expansion, the results of force measurement of displacement and deformation were recorded continuously by a program specialized in the field of measurement technology - known as "CATMAN - EASY" [21]. Expansion rock bolts used in the study form the basis of mining excavation supports at underground mines of the Legnica-Głogów Copper District (LGOM). Rod bolts with a length $1.8 \mathrm{~m}, 3.6 \mathrm{~m}$ and $5.2 \mathrm{~m}$ were tested. Rock bolt with a length $1.8 \mathrm{~m}$ was equipped with expansion shell with a length $0.095 \mathrm{~m}$ whereas bolts with a length $3.6 \mathrm{~m}$ and $5.2 \mathrm{~m}$ were equipped with expansion shell with a length $0.24 \mathrm{~m}$ (Figs. 2, 3). For all free bolts, the diameter of smooth rod was $0.0183 \mathrm{~m}$. A detailed description of used rock bolts can be found in the literature $[22,23]$. In order for laboratory studies to best satisfy mining conditions, dual bushings filled with concrete with a compressive strength of at least $75 \mathrm{MPa}$ were used at the laboratory test facility. Openings with a diameter of $0.0375 \mathrm{~m}$ were made in the $0.22 \mathrm{~m}$ diameter cylindrical concrete blocks. Additionally, for bolts with a length $3.6 \mathrm{~m}$ and $5.2 \mathrm{~m}$ rock cores obtained from underground excavations were used. Rock cores had holes with a diameter $0.026 \mathrm{~m}$ and characterized compressive strength up to $100 \mathrm{MPa}$. 


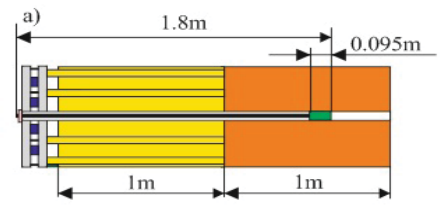

b)
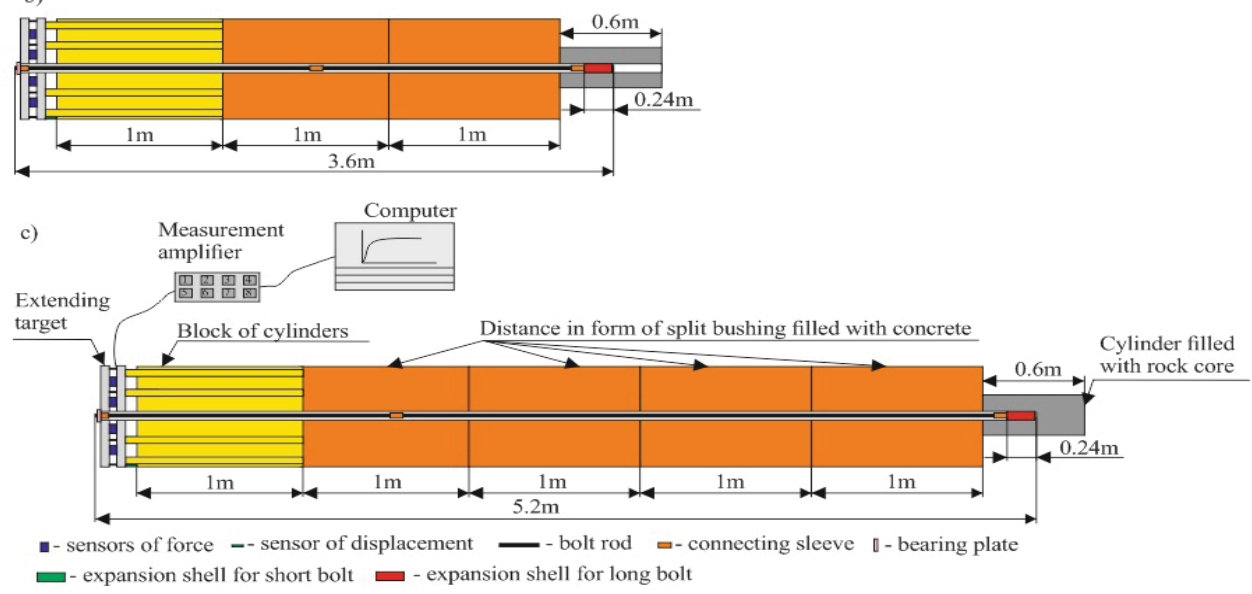

Fig. 2. Arrangement of sensors and elements of rock bolt support on the laboratory test facility; a) rock bolt support with a length $1.8 \mathrm{~m}, \mathrm{~b}$ ) rock bolt support with a length $3.6 \mathrm{~m}, \mathrm{c}$ ) rock bolt support with a length $5.2 \mathrm{~m}$.

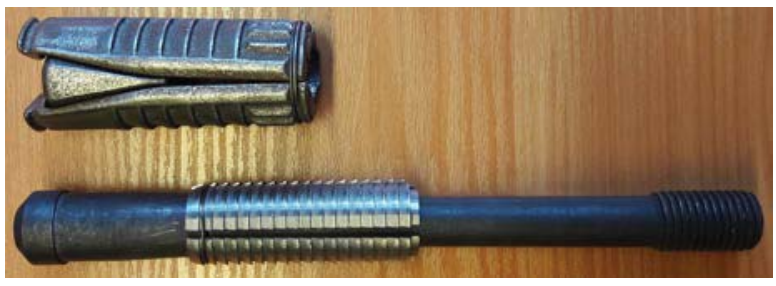

Fig. 3. Expansion shell; upper with diameter $0.036 \mathrm{~m}$ equipped with three jaws for bolt with a length $1.8 \mathrm{~m}$, lower with diameter $0.0254 \mathrm{~m}$ equipped with four jaws for bolt with a length $3.6 \mathrm{~m}$ and $5.2 \mathrm{~m}$ (photo: K. Skrzypkowski).

\subsection{Work done by short and long expansion rock bolts}

The aim of the study was to obtain load-displacement characteristics on the basis of which it will be possible to determine the amount of absorbed energy. During tests the results of force and displacement characteristics were recorded continuously and visualization and evaluation of the measurement were tracked on-going. In addition, after the tests were completed, reports documenting the results of the measurements were created and then stored as an ASCII file extension. Then the field under the curve by means of Simpson method was integrated. Furthemore for elastic and plastic ranges a amount of absorbed energy were determined. Examples of the characteristic parameters obtained in the tests are shown in Figure 4. 
a)

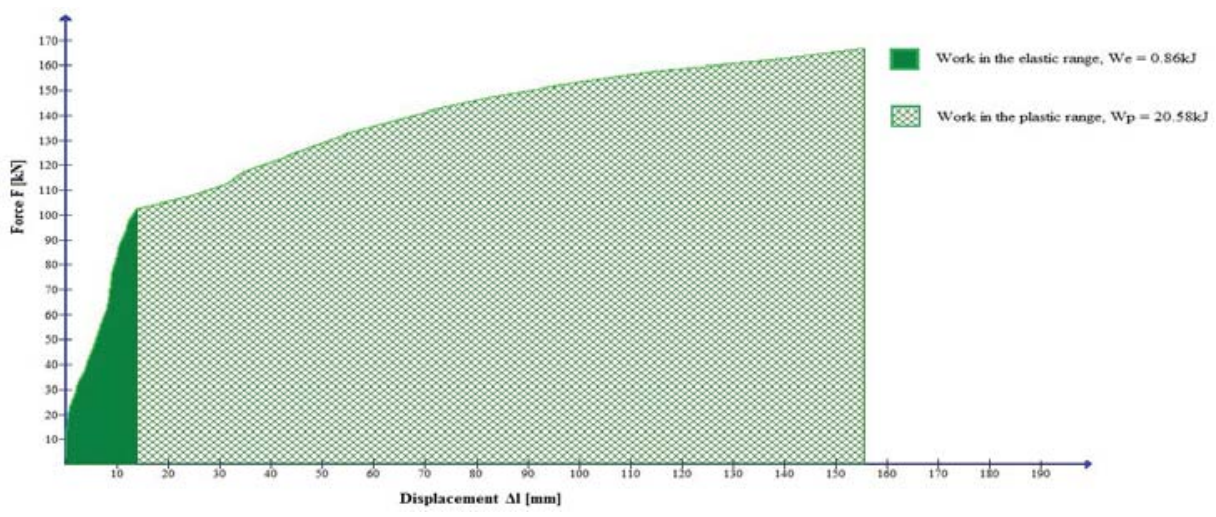

b)

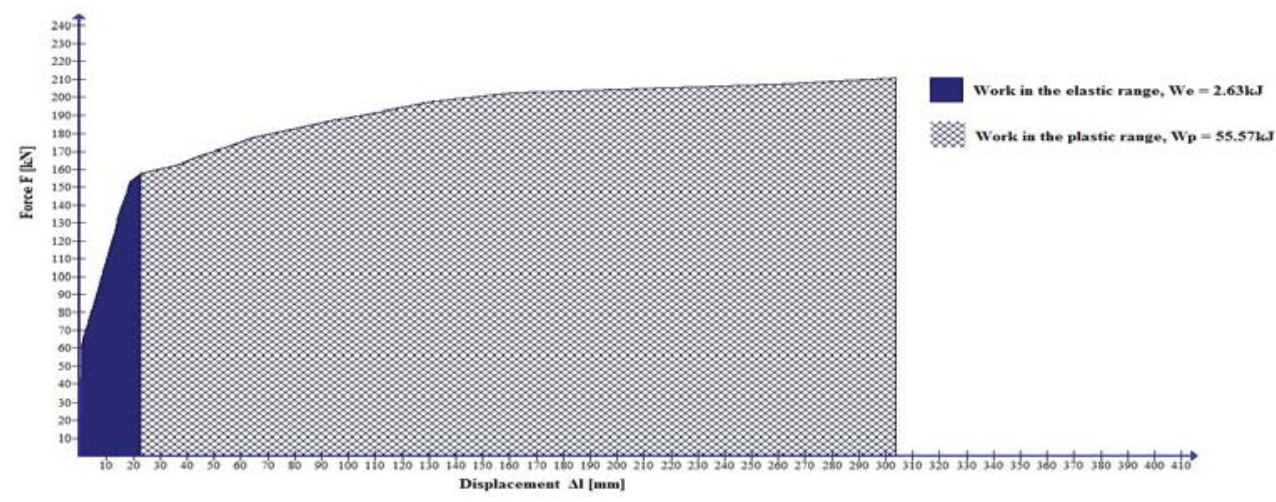

c)

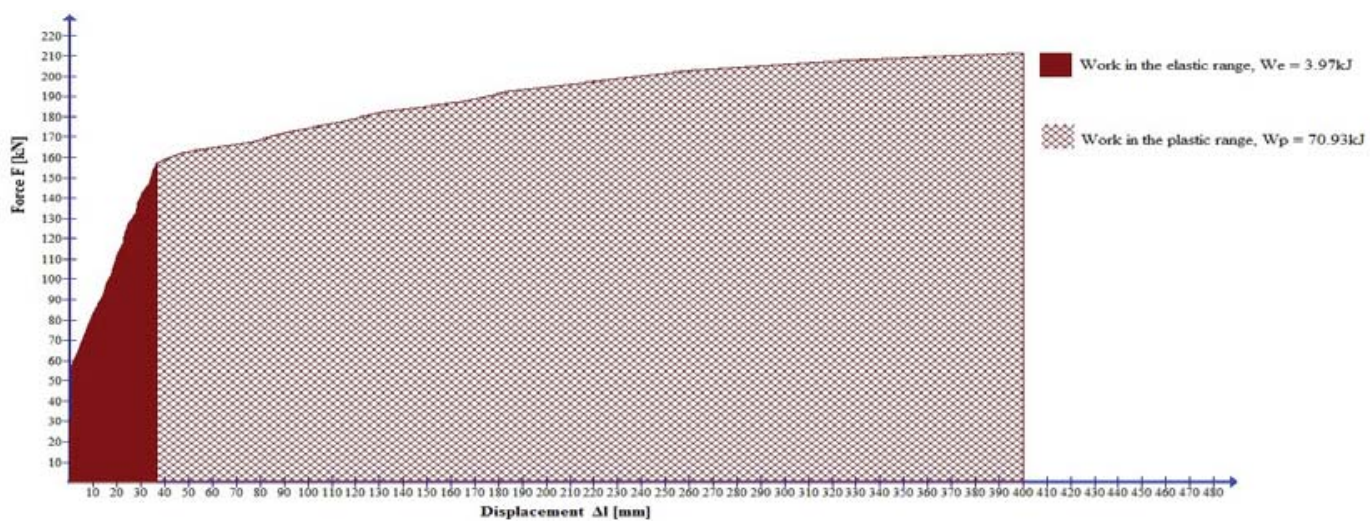

Fig. 4. Energy-absorbing by rock bolt support; a) with a length $1.8 \mathrm{~m}, \mathrm{~b}$ ) with a length $3.6 \mathrm{~m}, \mathrm{c}$ ) with a length $5.2 \mathrm{~m}$. 
Based on Figure 4, it can be concluded that the most energy is absorbed by the support, which is the longest. This is due to the structural features of the bolt and the connecting rods using the connecting sleeves. The $5.2 \mathrm{~m}$ long bolt consists of three rods, which, together with the connecting sleeves and the bearing plate and the slide out from the hole, constitute a deformation of $0.4 \mathrm{~m}$. This corresponds to a maximum breaking load of approximately $213 \mathrm{kN}$. On the Figure 4 the axes have units $\mathrm{kN}$ and $\mathrm{mm}$ in order to determine the work in $\mathrm{kJ}$. A $1.8 \mathrm{~m}$ long bolt is capable of performing work (absorbing energy) of about $21 \mathrm{~kJ}$. On the other hand, bolts with a length of $3.6 \mathrm{~m}$ consume more than $58 \mathrm{~kJ}$. The greatest amount of energy was absorbed by bolts of $5.2 \mathrm{~m}$ in length, almost 75 $\mathrm{kJ}$. In the elastic range of $3.6 \mathrm{~m}$ and $5.2 \mathrm{~m}$, the bolt absorbs $305 \%$ and $461 \%$ more energy, respectively, than the bolt of $1.8 \mathrm{~m}$. On the other hand, in terms of plasticity, the bolts of $3.6 \mathrm{~m}$ and $5.2 \mathrm{~m}$ are $270 \%$ and $344 \%$ respectively, compared to the $1.8 \mathrm{~m}$ bolt.

\section{Conclusions}

In recent years, the concept of bearing capacity of a rock bolt support, previously identified primarily with the ability to carry a specific load that grows over a long period of time, is related to the load that has grown rapidly - to the dynamic load. With this situation we are increasingly dealing with the successive increase in depth of exploitation resulting in the increase of stresses in the rock mass and to generate seismic events, rock masses and bumps. Dynamic dynamics induces the study and determination of the amount of energy absorbed by commonly used bolt support and to seek more effective ways of rock mass reinforcement. The absorbtion of energy through the bolt support is subject to ongoing research in many scientific research centers around the world. There are more and more new concepts, the common feature of which is the ability to maintain a high carrying capacity while accepting much larger displacement and deformation of the support. Rock bolts support used in dynamic hazards are characterized by varying geometry of structural elements, different grades of steel and addition of special energy absorbers.

Bolt supports are able to absorb the energy of several dozen kJ.

In Polish mining, most of the rock bolt support are used in the underground exploitation of copper ore deposits in the Legnica-Głogów Copper District (LGOM) (about $2 \div 3$ million units). Bolt support with a length from $1.2 \mathrm{~m}$ to $2.6 \mathrm{~m}$ is characterized as short. On the other hand, $3.6 \mathrm{~m}, 5 \mathrm{~m}$ and $7 \mathrm{~m}$ bolts are used as additional, most commonly used for rebuildings and on the crossings of excavations. Expansion Rock bolt support with is able to absorb energy:

a) $21 \mathrm{~kJ}$ for a length $1.8 \mathrm{~m}$ and with a shell head with a $0.036 \mathrm{~m}$ diameter, b) $58.2 \mathrm{~kJ}$ for a length of $3.6 \mathrm{~m}$ and with a shell head with a $0.0254 \mathrm{~m}$ diameter, c) $74.9 \mathrm{~kJ}$ for a length of $5.2 \mathrm{~m}$ and with a shell head with a $0.0254 \mathrm{~m}$ diameter.

The amount of absorbed energy by the rock bolt support constitutes only a few percent of the total energy generated by the rock mass, so it is so important to create new construction solutions dedicated to ever deeper exploitation levels.

The study was carried out within the framework of dean's grant for young scientists no. 15.11.100.075

\section{References}

1. L.St-Pierre, F.P. Hassani, P.H. Radziszewski, J. Ouellet, Int. J. Rock Mech. Mining Sci. 46, 1 (2009)

2. K. Skrzypkowski, Utility PL 68412 Y1 (2016) 
3. S. Prusek, M. Rotkegel, Malecki Ł, Eng. Struct. 75 (2014)

4. A. Zorychta, Monthly of State Mining Authority 2 (1996)

5. C.C. Li, Int. J. Rock Mech. Min. Sci. 47, 3 (2010)

6. P.P. Kaiser, M. Cai, JRMGE. 4, 3 (2012)

7. K. Skrzypkowski, Mining Review. 68, 4 (2012)

8. W. Korzeniowski, K. Skrzypkowski, Mining Review, 66, 3-4 (2011)

9. A. Ansell, Tunn. Undergr. Sp. Technol. 20, 4 (2005)

10. A.J. Jager, Rock support in mining and underground construction, Balkema (1992)

11. W.D. Ortlepp, J.J. Borman, N. Erasmus, Rockbursts and Seismisicity in Mines, South African Institute of Mining and Metallurgy (2001)

12. W. Pytel, P. Mertuszka, K. Szeptun, Ground Support, Lulea (2016)

13. NMX Dynamics, www.nmvgroup.se (2017)

14. W. Korzeniowski, K. Skrzypkowski, K. Zagórski, SGeM, 39, 1 (2017)

15. DYNATORK, www.dsiunderground.com (2017)

16. Yield-Lok, www.jennmar.com (2017)

17. B. Neugebauer, Mining\&Construction, 3 (2008)

18. Garfordcable, www.garfordcablebolts.com (2017)

19. M. He, W. Gong, J. Wang, P. Qi, Z. Tao, S. Du, Y. Peng, Int. J. Rock Mech. Mining Sci. 67, (2014)

20. A. Nierobisz, International Mining Forum, London (2007)

21. W. Korzeniowski, K. Skrzypkowski, Ł. Herezy, Arch. Min. Sci. 60, 1 (2015)

22. K. Skrzypkowski, W. Korzeniowski, K. Zagórski, P. Dudek, SGeM, 39, 3 (2017)

23. K. Skrzypkowski, XXVI School of Underground Mining. Kraków (2017) 